\title{
Enhanced energy storage properties of barium strontium titanate ceramics prepared by sol-gel method and spark plasma sintering
}

\author{
Yu Hui Huang ${ }^{\mathrm{a}, \mathrm{b}, \mathrm{c}}$, Yong Jun $\mathrm{Wu}^{\mathrm{a}, \mathrm{b}, \mathrm{c}, *}$, Juan $\mathrm{Li}^{\mathrm{d}, *}$, Bing Liu ${ }^{\mathrm{b}}$, Xiang Ming Chen ${ }^{\mathrm{b}}$ \\ ${ }^{\mathrm{a}}$ State Key Laboratory of Silicon Materials, Zhejiang University, Hangzhou 310027, China. \\ ${ }^{\mathrm{b}}$ Laboratory of Dielectric Materials, School of Materials Science and Engineering, Zhejiang
}

University, Hangzhou 310027, China

${ }^{\mathrm{c}}$ Cyrus Tang Center for Sensor Materials and Applications, Zhejiang University, Hangzhou

310027, China

${ }^{\mathrm{d}}$ College of Materials Science and Engineering, Zhejiang University of Technology, Hangzhou 310006, China

\begin{abstract}
Dense $\mathrm{Ba}_{0.4} \mathrm{Sr}_{0.6} \mathrm{TiO}_{3}$ ceramics with fine grains and uniform microstructure were prepared by sol-gel method and spark plasma sintering (SPS). The dielectric properties, microstructures, and energy storage performance of spark plasma sintered $\mathrm{Ba}_{0.4} \mathrm{Sr}_{0.6} \mathrm{TiO}_{3}$ ceramics were evaluated. Fine $\mathrm{Ba}_{0.4} \mathrm{Sr}_{0.6} \mathrm{TiO}_{3}$ powders were synthesized by sol-gel method at above $750^{\circ} \mathrm{C}$. SPS technique showed its advantages in suppressing exaggerated grain growth and increasing the relative density of $\mathrm{Ba}_{0.4} \mathrm{Sr}_{0.6} \mathrm{TiO}_{3}$ ceramics. Diffuse phase transition and nearly linear $\mathrm{P}-\mathrm{E}$ behavior were observed in all samples. Moderate dielectric constant ( 960), low dielectric loss
\end{abstract}

${ }^{*}$ Corresponding author. Tel.: 86-571-87951410; fax: 86-571-87951410.

E-mail address: yongjunwu@zju.edu.cn (Y.J. Wu), juanli@zjut.edu.cn (J. Li). 
( 0.003), high electrical breakdown strength $(\sim 240 \mathrm{kV} / \mathrm{cm})$, significantly enhanced energy storage density $\left(\sim 1.23 \mathrm{~J} / \mathrm{cm}^{3}\right)$ and ultrahigh energy storage efficiency ( 94.52\%) were obtained in $\mathrm{Ba}_{0.4} \mathrm{Sr}_{0.6} \mathrm{TiO}_{3}$ ceramics by using sol-gel method and spark plasma sintering.

Keywords: Energy storage, Sol-gel processes, Barium strontium titanate, Spark plasma sintering

\section{Introduction}

Among the current electrical energy storage devices, dielectric capacitors possess the fastest charging and discharging rates, which are indispensable in the pulsed power systems[1,2]. However, their energy storage density is at least one order of magnitude lower than their electrochemical counterparts, such as batteries and double-layer supercapacitors[3]. In order to reduce the size and cost of capacitors, high energy density dielectrics are highly desirable. The maximum energy density $\left(J_{\max }\right)$ is determined by the dielectric constant $\left(\varepsilon_{r}\right)$ and dielectric breakdown strength $\left(E_{b}\right)$, which is generally expressed as

$$
J_{\max }=\frac{1}{2} \varepsilon_{0} \varepsilon_{r} \mathrm{E}_{\mathrm{b}}^{2}
$$

for linear dielectric materials ( $\varepsilon_{0}$ is the permittivity of free space)[4]. As can be seen from the equation, $J_{\max }$ increases proportionately with the square of $E_{b}$, which means energy density is largely determined by the breakdown strength. However, due to the pores, cracks and other defects in ceramics, there is a large gap between the measured 
results and the intrinsic values of breakdown strength. For instance, the theoretical calculation showed that the maximum energy storage density could reach as high as 8 $\mathrm{J} / \mathrm{cm}^{3}$ at $1000 \mathrm{kV} / \mathrm{cm}$ for $\mathrm{Ba}_{1-x} \mathrm{Sr}_{x} \mathrm{TiO}_{3}(\mathrm{BST})$ materials[5], but in practice the value is just around $0.4 \mathrm{~J} / \mathrm{cm}^{3}$ at $120 \mathrm{kV} / \mathrm{cm}[6]$. This leaves huge room for further improvement of breakdown strength in ceramics.

Glass and/or oxides, such as $\mathrm{Al}_{2} \mathrm{O}_{3}, \mathrm{ZnO}, \mathrm{MgO}$ have been used to modify the microstructure of BST ceramics and increase the breakdown strength[7-11]. Besides, breakdown strength also shows a strong dependence on the grain size[12,13], as the relation expressed[7,14]:

$$
E_{b} \propto G^{-t}
$$

where $E_{b}$ is the breakdown strength, $\mathrm{G}$ is the average grain size, and $\mathrm{t}$ is a constant. So the grain refinement also contributes to the improvement of breakdown strength. To synthesize BST ultrafine powders, various methods such as co-precipitation, hydrothermal method, spray pyrolysis, modified Pechini route and sol-gel method have been employed[15-23]. Among these, sol-gel method is thought to be highly promising for achieving homogeneous powders and avoiding hard agglomeration due to the large gas release during citric acid decomposition and organics burning[17]. But unfortunately, dense BST ceramics with ultrafine grain size (especially when grain size is lower than $100 \mathrm{~nm}$ ) are usually difficult to be achieved due to the uncontrolled grain growth during the conventional sintering process[24]. Therefore, another advanced sintering method named spark plasma sintering (SPS) is applied to fabricate BST ceramics in this work. During the SPS process, high pressure and 
pulsed electrical current will work together to accomplish the densification with short sintering periods (usually several minutes) and low sintering temperature[25-27]. These are advantageous in suppressing abnormal grain growth[28-32].

Additionally, for practical applications, energy storage efficiency $(\eta)$ also needs to be considered. The efficiency is defined as the ratio of recoverable energy density to the stored energy density. During depolarization process, part of the stored energy is exhausted as heat[33]. This is detrimental to the performance and reliability of capacitors. To the best of our knowledge, there are few reports about the efficiency greater than $90 \%$ obtained in nonlinear dielectrics[34-38]. This is mainly because the efficiency would decrease rapidly with the increasing applied electric field due to the conduction loss[39,40].

In this research, sol-gel method and spark plasma sintering were employed to prepare dense $\mathrm{Ba}_{0.4} \mathrm{Sr}_{0.6} \mathrm{TiO}_{3}$ ceramics with fine grains and uniform microstructure. The dielectric properties, microstructures, and energy storage performance of spark plasma sintered $\mathrm{Ba}_{0.4} \mathrm{Sr}_{0.6} \mathrm{TiO}_{3}$ ceramics were evaluated.

\section{Experimental details}

Ultrafine $\mathrm{Ba}_{0.4} \mathrm{Sr}_{0.6} \mathrm{TiO}_{3}$ powders were synthesized by sol-gel method. Barium carbonate $\left(\mathrm{BaCO}_{3}, 99.99 \%\right)$, strontium carbonate $\left(\mathrm{SrCO}_{3}, 99.9 \%\right)$, tetrabutyl titanate $\left(\mathrm{Ti}\left(\mathrm{C}_{4} \mathrm{H}_{9} \mathrm{O}\right)_{4}, 98 \%\right)$, citric acid $(\mathrm{CA}, 99.5 \%)$ were used as starting materials. $0.1 \mathrm{~mol}$ of $\mathrm{Ti}\left(\mathrm{C}_{4} \mathrm{H}_{9} \mathrm{O}\right)_{4}$ was dissolved into 2 mol ethylene glycol (EG). Subsequently, $0.5 \mathrm{~mol}$ of citric acid was directly added to the solution. $20 \mathrm{ml}$ water was blended into the 
solution to help dissolving CA. A bit of white precipitate was observed at first but immediately dissolved after stirring for $1 \mathrm{~h}$ on a magnetic stirrer. Then $0.04 \mathrm{~mol}$ of $\mathrm{BaCO}_{3}$ and $0.06 \mathrm{~mol}$ of $\mathrm{SrCO}_{3}$ were added to this solution. Five drops of nitric acid $\left(\mathrm{HNO}_{3}, 65 \%\right)$ were added to help dissolving the carbonates. The mixed solution was put into a water bath and stirred at $70^{\circ} \mathrm{C}$ until it became pale brown and transparent. Then it was dried at $120^{\circ} \mathrm{C}$ for $48 \mathrm{~h}$ with a color change from pale brown to dark brown. The xerogel was heated at $300^{\circ} \mathrm{C}$ for $30 \mathrm{~min}$ and subsequently calcined at $550^{\circ} \mathrm{C}, 650^{\circ} \mathrm{C}, 750^{\circ} \mathrm{C}, 850^{\circ} \mathrm{C}, 950^{\circ} \mathrm{C}$ and $1050^{\circ} \mathrm{C}$, respectively. Fig. 1 illustrates the above process in a simplified sequence flow chart.

To prepare BST ceramics by SPS, the calcined powders were placed in a graphite die and sintered at $1000^{\circ} \mathrm{C}$ for 5 min under a vacuum of $6 \mathrm{~Pa}$ with an SPS apparatus (SPS-1050, SPS Syntex Inc., Kanagawa, Japan). During the period of heating, a pressure of $30 \mathrm{MPa}$ was applied to the sample. The heating rate was $100^{\circ} \mathrm{C} / \mathrm{min}$ from room temperature to $900^{\circ} \mathrm{C}, 40^{\circ} \mathrm{C} / \mathrm{min}$ from $900^{\circ} \mathrm{C}$ to $980^{\circ} \mathrm{C}$, and $20^{\circ} \mathrm{C} / \mathrm{min}$ from $980^{\circ} \mathrm{C}$ to $1000^{\circ} \mathrm{C}$. All the spark plasma sintered samples were thermally treated at $1100^{\circ} \mathrm{C}$ for $3 \mathrm{~h}$ in air and coated on each major face with $\mathrm{Au}$ electrodes.

The bulk density of the sintered samples was measured by the Archimedes method. The crystalline phases of powders prepared by sol-gel method at different calcination temperatures were characterized by X-ray diffraction (XRD, D/MAX 2550/PC, Rigaku, Tokyo, Japan) using $\mathrm{Cu} \mathrm{Ka}$ radiation. The morphology of the powders and the microstructures of the sintered samples were observed with field 
emission scanning electron microscopy (SEM, S-4800, Hitachi, Tokyo, Japan). The grain size of the sintered samples was determined from the SEM micrographs using the linear intercept method[41]. The dielectric properties were evaluated with a broadband dielectric spectrometer (Turnkey Concept 80, Novocontrol Technologies $\mathrm{GmbH} \&$ Co. KG, Hundsangen, Germany) in a broad range of temperature $(140-400 \mathrm{~K})$ and frequency $(100 \mathrm{~Hz}-1 \mathrm{MHz})$ with a heating rate of $2 \mathrm{~K} / \mathrm{min}$. A ferroelectric test system (Premier II, Radiant Tech. Inc., NM, USA) were used for $P-E$ loops measurement. The energy storage densities and efficiencies were calculated from the $P-E$ loops.

\section{Results and discussion}

\subsection{Phase characterization and microstructure observation}

Fig. 2 shows the XRD patterns of $\mathrm{Ba}_{0.4} \mathrm{Sr}_{0.6} \mathrm{TiO}_{3}$ powders calcined at $550^{\circ} \mathrm{C}$, $650^{\circ} \mathrm{C}, 750^{\circ} \mathrm{C}, 850^{\circ} \mathrm{C}, 950^{\circ} \mathrm{C}, 1050^{\circ} \mathrm{C}$, respectively. Major phase has been formed even at a very low temperature of $550^{\circ} \mathrm{C}$ and the amount of the secondary phase of $(\mathrm{Ba}, \mathrm{Sr}) \mathrm{CO}_{3}$ decreases with the increase of calcination temperature. The synthesis temperature of BST powders by sol-gel method in this work $\left(750^{\circ} \mathrm{C}\right)$ is at least $400^{\circ} \mathrm{C}$ lower than that by the conventional solid state reaction $\left(1150^{\circ} \mathrm{C}\right)[6,8]$. The morphology of $\mathrm{Ba}_{0.4} \mathrm{Sr}_{0.6} \mathrm{TiO}_{3}$ powders is shown in Fig. 3. Ultrafine and uniform particles are obtained. The average particle sizes of BST powders calcined at $750^{\circ} \mathrm{C}$, $850^{\circ} \mathrm{C}, 950^{\circ} \mathrm{C}$ and $1050^{\circ} \mathrm{C}$ are approximately $45 \mathrm{~nm}, 55 \mathrm{~nm}, 85 \mathrm{~nm}$ and $105 \mathrm{~nm}$, respectively. SEM micrographs on polished and thermally etched surfaces of BST 
ceramics sintered at $1000^{\circ} \mathrm{C}$ for 5 min by SPS are presented in Fig. 4. Dense microstructures with few pores, voids and microcracks are observed in all samples. The relative densities of all samples are above $99 \%$, which are consistent with the SEM results. Rapid sintering of SPS technique usually makes it possible for the samples to skip over the low temperature regime where the surface diffusion (non-densifying mechanisms) is active and to proceed directly to the elevated temperature regime where grain boundary and volume diffusion (densifying mechanisms) are predominant[24], which results in a rapid densification of BST ceramics. It should be noted that SPS is a very effective method to control the grain size of the BST ceramics due to a low sintering temperature $\left(1000^{\circ} \mathrm{C}\right)$ and a very short sintering period (5 min). The average grain sizes of BST ceramics prepared from powders calcined at $750^{\circ} \mathrm{C}, 850^{\circ} \mathrm{C}, 950^{\circ} \mathrm{C}$ and $1050^{\circ} \mathrm{C}$ are approximate $173 \mathrm{~nm}, 190$ $\mathrm{nm}, 201 \mathrm{~nm}$ and $238 \mathrm{~nm}$, respectively.

\subsection{Dielectric properties}

Fig. 5 shows the temperature dependence of the dielectric constant and dielectric loss at various frequencies for BST ceramics prepared from powders calcined at different temperatures. Diffuse dielectric peaks around 195K were observed for all samples, which should be corresponding to the transition from paraelectric to ferroelectric phase. Fig. 6 (a) shows the average grain size and the maximum dielectric constant $\left(\varepsilon_{p}\right)$ at $100 \mathrm{~Hz}$ of BST ceramics. The maximum dielectric constant $\left(\varepsilon_{p}\right)$ at Curie temperature $\left(T_{c}\right)$ increases with the calcination temperature of BST powders, which can be ascribed to the increase of the average grain size. According to 
the "series and parallel combination" model proposed by Shaikh[42], when the grain size is very small (usually less than $1 \mu \mathrm{m}$ ), the grains are assumed to be single domains. Thus, the grain boundary effect plays a key factor in the variation of dielectric constant and the domain wall contribution is absent. As grain boundaries are amorphous in nature, and have a lower dielectric constant than the ferroelectric grains. Therefore, larger grain size with less grain boundary content will possess a higher dielectric constant. Similar results have also been reported in many other material systems[43,44]. As shown in Fig. 6 (b) and Table 1, all samples possess a moderate dielectric constant and a low dielectric loss at room temperature, which is beneficial to the improvement of energy storage density and energy storage efficiency. The good dielectric performance mentioned above suggests that $\mathrm{Ba}_{0.4} \mathrm{Sr}_{0.6} \mathrm{TiO}_{3}$ ceramics prepared by sol-gel method and spark plasma sintering could be a promising candidate for energy storage application.

\subsection{Energy storage properties}

Fig. 7 shows $P-E$ loops at room temperature and $60 \mathrm{~Hz}$ for BST ceramics under the maximum applicable electric field (close to dielectric breakdown strength, $E_{b}$ ). All samples prepared in this study possess much higher $E_{b}$ than that of the sample prepared by the conventional sintering method because of the much smaller grain size. The BST sample prepared from the powders calcined at $750^{\circ} \mathrm{C}$ shows a much smaller $E_{b}$ than that of the sample prepared from the powders calcined at $850^{\circ} \mathrm{C}$ even it has a smaller grain size. This may be attributed to the very small amount of the secondary phase in the sample prepared from the powders calcined at $750^{\circ} \mathrm{C}$. As shown in Fig. 7, 
nearly linear $P-E$ behavior of BST ceramics were observed for all samples. The electrical energy density charged $\left(J_{c}\right)$ is equal to the integral of the area enclosed by charge curve and y-axis. The electrical energy density discharged $\left(J_{d}\right)$ is equal to the integral of the area enclosed by discharge curve and y-axis. The unreleased energy density or the energy loss is equal to the integral of the area enclosed by charge and discharge curves. The ratio $J_{d} / J_{c}$ can be used to evaluate the energy storage efficiency ( $\eta$ ). As marked in Fig. 7, all four samples exhibit a much higher maximum energy storage density than that of the BST samples prepared by the conventional solid state method $\left(J_{c}=0.37 \mathrm{~J} / \mathrm{cm}^{3}\right)[6]$. Moreover, the highest $J_{c}$ value obtained in this work $(1.23$ $\mathrm{J} / \mathrm{cm}^{3}$ )is comparable with that of the commercial capacitor film (biaxially oriented polypropylenes)[45]. Obviously, the moderate dielectric constant (>800) and the high dielectric breakdown strengths $(>200 \mathrm{kV} / \mathrm{cm})$ due to the fine grains and dense microstructure play a key role in the improvement of the energy storage density.

The energy storage density and efficiency as a function of electric field for BST ceramics are presented in Fig. 8. It can be seen that the energy storage density increases with the increase of applied electric field, while the energy storage efficiency shows a contrary tendency. The energy loss due to the conduction and dielectric loss of BST ceramics increases as the electric field rises, which leads to the decrease of energy storage efficiency. Despite that, as shown in Fig. 8 (b), the decrease of energy storage efficiency with the increase of electric field is well suppressed. The BST samples prepared from powders calcined at $850^{\circ} \mathrm{C}$ and $950^{\circ} \mathrm{C}$ exhibit a high energy storage efficiency of $94 \%$ even at a very high electric field of 
$240 \mathrm{kV} / \mathrm{cm}$. Altogether, as shown in Table 2, BST ceramics with excellent energy storage properties of $J_{c}=1.23 \mathrm{~J} / \mathrm{cm}^{3}$ and $\eta=94.52 \%$ are obtained by using sol-gel method and spark plasma sintering.

\section{Conclusions}

Ultrafine and uniform $\mathrm{Ba}_{0.4} \mathrm{Sr}_{0.6} \mathrm{TiO}_{3}$ powders were synthesized by sol-gel method. Spark plasma sintering was successfully used to prepare dense BST ceramics. The fine grain and dense microstructure played a key role in the improvement of dielectric breakdown strength and the decrease of dielectric loss. BST ceramics with significantly improved energy storage density of $1.23 \mathrm{~J} / \mathrm{cm}^{3}$ and energy storage efficiency of $94.52 \%$ were obtained by using sol-gel method and spark plasma sintering. These BST ceramics are promising candidates for electrical energy storage materials for pulsed power applications and regenerative braking system.

\section{Acknowledgments}

This work was financially supported by National Science Foundation of China under Grant Nos. 51572237 and 51302245, Chinese National Basic Research Program under grant number 2015CB654601, the Specialized Research Fund for the Doctoral Program of Higher Education of China under Grant No. 20130101110085, Zhejiang Provincial Natural Science Foundation under Grant No. LZ17E020003, Zhejiang Provincial Top Key Discipline of New Materials and Process Engineering, and the 111 project. 


\section{References}

[1] C. Liu, F. Li, L.P. Ma, H.M. Cheng, Advanced materials for energy storage, Adv. Mater. 22 (2010) E28-62.

[2] S.A. Sherrill, P. Banerjee, G.W. Rubloff, S.B. Lee, High to ultra-high power electrical energy storage, Phys. Chem. Chem. Phys. 13 (2011) 20714-20723.

[3] X. Zhang, Y. Shen, Q. Zhang, L. Gu, Y. Hu, J. Du, Y. Lin, C.W. Nan, Ultrahigh energy density of polymer nanocomposites containing $\mathrm{BaTiO}_{3} @ \mathrm{TiO}_{2}$ nanofibers by atomic-scale interface engineering, Adv. Mater. 27 (2015) 819-824.

[4] Z.M. Dang, J.K. Yuan, S.H. Yao, R.J. Liao, Flexible nanodielectric materials with high permittivity for power energy storage., Adv. Mater. 25 (2013) 6334-6365.

[5] N.H. Fletcher, A.D. Hilton, B.W. Ricketts, Optimization of energy storage density in ceramic capacitors, J. Phys. D-Applied Phys. 29 (1996) 253-258.

[6] Q. Zhang, L. Wang, J. Luo, Q. Tang, J. Du, Improved energy storage density in barium strontium titanate by addition of $\mathrm{BaO}-\mathrm{SiO}_{2}-\mathrm{B}_{2} \mathrm{O}_{3}$ glass, J. Am. Ceram. Soc. 92 (2009) 1871-1873.

[7] J. Wang, C. Xu, B. Shen, J. Zhai, Enhancing energy storage density of (Ba, Sr) $\mathrm{TiO}_{3}$ ceramic particles by coating with $\mathrm{Al}_{2} \mathrm{O}_{3}$ and $\mathrm{SiO}_{2}$, J. Mater. Sci. Mater. Electron. 24 (2013) 3309-3314.

[8] Y.H. Huang, Y.J. Wu, W.J. Qiu, J. Li, X.M. Chen, Enhanced energy storage density of $\mathrm{Ba}_{0.4} \mathrm{Sr}_{0.6} \mathrm{TiO}_{3}-\mathrm{MgO}$ composite prepared by spark plasma sintering, $\mathrm{J}$. 
Eur. Ceram. Soc. 35 (2015) 1469-1476.

[9] G. Dong, S. Ma, J. Du, J. Cui, Dielectric properties and energy storage density in $\mathrm{ZnO}$-doped $\mathrm{Ba}_{0.3} \mathrm{Sr}_{0.7} \mathrm{TiO}_{3}$ ceramics, Ceram. Int. 35 (2009) 2069-2075.

[10] D. Yi, J. Yuan, H. Liu, Y. Shen, Y.H. Lin, C.W. Nan, X. Xi, J. He, Influence of $\mathrm{Al}_{2} \mathrm{O}_{3}$ additive on the dielectric behavior and energy density of $\mathrm{Ba}_{0.5} \mathrm{Sr}_{0.5} \mathrm{TiO}_{3}$ ceramics, J. Electroceram. 29 (2012) 95-98.

[11] S. Xiao, S. Xiu, W. Zhang, B. Shen, J. Zhai, Y. Zhang, Effects of $\mathrm{Ba}_{\mathrm{x}} \mathrm{Sr}_{1-\mathrm{x}} \mathrm{TiO}_{3}$ ceramics additives on structure and energy storage properties of $\mathrm{Ba}_{0.4} \mathrm{Sr}_{0.6} \mathrm{TiO}_{3}-\mathrm{BaO}-\mathrm{B}_{2} \mathrm{O}_{3}-\mathrm{Al}_{2} \mathrm{O}_{3}-\mathrm{SiO}_{2}$ glass-ceramic, J. Alloys Compd. 675 (2016) 15-21.

[12] Z. Song, H. Liu, S. Zhang, Z. Wang, Y. Shi, H. Hao, M. Cao, Z. Yao, Z. Yu, Effect of grain size on the energy storage properties of $\left(\mathrm{Ba}_{0.4} \mathrm{Sr}_{0.6}\right) \mathrm{TiO}_{3}$ paraelectric ceramics, J. Eur. Ceram. Soc. 34 (2014) 1209-1217.

[13] Z. Song, H. Liu, H. Hao, S. Zhang, M. Cao, Z. Yao, Z. Wang, W. Hu, The effect of grain boundary on the energy paraelectric ceramics by varying grain sizes, IEEE Trans. Ultrason. Ferroelectr. Freq. Control. 62 (2015) 609-616.

[14] E.K. Beauchamp, Effect of microstructure on pulse electrical strength of $\mathrm{MgO}$, J. Am .Ceram. Soc. 54 (1971) 484-487.

[15] K. Verma, S. Sharma, D.K. Sharma, R. Kumar, R. Rai, Sol-gel processing and characterization of nanometersized $(\mathrm{Ba}, \mathrm{Sr}) \mathrm{TiO}_{3}$ ceramics, Adv. Mater. Lett. 3 (2012) 44-49.

[16] R.M. Mahani, I.K. Battisha, M. Aly, A.B. Abou-Hamad, Structure and 
dielectric behavior of nano-structure ferroelectric $\mathrm{Ba}_{\mathrm{x}} \mathrm{Sr}_{1-\mathrm{x}} \mathrm{TiO}_{3}$ prepared by sol-gel method, J. Alloys Compd. 508 (2010) 354-358.

[17] C. Shen, Q.F. Liu, Q. Liu, Sol-gel synthesis and spark plasma sintering of $\mathrm{Ba}_{0.5} \mathrm{Sr}_{0.5} \mathrm{TiO}_{3}$, Mater. Lett. 58 (2004) 2302-2305.

[18] M.L. Li, H. Liang, M.X. Xu, Simple oxalate precursor route for the preparation of brain-like shaped barium-strontium titanate: $\mathrm{Ba}_{0.6} \mathrm{Sr}_{0.4} \mathrm{TiO}_{3}$, Mater. Chem. Phys. 112 (2008) 337-341.

[19] Y.B. Khollam, S.B. Deshpande, H.S. Potdar, S.V. Bhoraskar, S.R. Sainkar, S.K. Date, Simple oxalate precursor route for the preparation of barium-strontium titanate: $\mathrm{Ba}_{1-\mathrm{x}} \mathrm{Sr}_{\mathrm{x}} \mathrm{TiO}_{3}$ powders, Mater. Charact. 54 (2005) 63-74.

[20] K.A. Razak, A. Asadov, J. Yoo, E. Haemmerle, W. Gao, Structural and dielectric properties of barium strontium titanate produced by high temperature hydrothermal method, J. Alloys Compd. 449 (2008) 19-23.

[21] A. Ianculescu, D. Berger, M. Viviani, C.E. Ciomaga, L. Mitoseriu, E. Vasile, N. Drăgan, D. Crişan, Investigation of $\mathrm{Ba}_{1-\mathrm{x}} \mathrm{Sr}_{\mathrm{x}} \mathrm{TiO}_{3}$ ceramics prepared from powders synthesized by the modified Pechini route, J. Eur. Ceram. Soc. 27 (2007) 3655-3658.

[22] S.H. Choi, Y.N. Ko, J.K. Lee, Y.C. Kang, Dielectric properties of nano-sized $\mathrm{Ba}_{0.7} \mathrm{Sr}_{0.3} \mathrm{TiO}_{3}$ powders prepared by spray pyrolysis, Ceram. Int. 38 (2012) $4029-4033$.

[23] P.R. Arya, P. Jha, A.K. Ganguli, Synthesis, characterization and dielectric properties of nanometer-sized barium strontium titanates prepared by the 
polymeric citrate precursor method, J. Mater. Chem. 13 (2003) 415-423.

[24] B. Li, X. Wang, M. Cai, L. Hao, L. Li, Densification of uniformly small-grained $\mathrm{BaTiO}_{3}$ using spark-plasma-sintering, Mater. Chem. Phys. 82 (2003) 173-180.

[25] W. Chen, U. Anselmi-Tamburini, J.E. Garay, J. Groza, Z. Munir, Fundamental investigations on the spark plasma sintering/synthesis process I. Effect of dc pulsing on reactivity, Mater. Sci. Eng. A. 394 (2005) 132-138.

[26] U. Anselmi-Tamburini, J.E. Garay, Z.A. Munir, Fundamental investigations on the spark plasma sintering/synthesis process III. Current effect on reactivity, Mater. Sci. Eng. A. 407 (2005) 24-30.

[27] U. Anselmi-Tamburini, S. Gennari, J.E. Garay, Z.A. Munir, Fundamental investigations on the spark plasma sintering/synthesis processII. Modeling of current and temperature distributions, Mater. Sci. Eng. A. 394 (2005) 139-148.

[28] Y.J. Wu, N. Wang, S.Y. Wu, X.M. Chen, Transparent barium strontium titanate ceramics prepared by spark plasma sintering, J. Am. Ceram. Soc. 94 (2011) 1343-1345.

[29] L. Gao, J.S. Hong, H. Miyamoto, S.D.D.L. Torre, Bending strength and microstructure of $\mathrm{Al}_{2} \mathrm{O}_{3}$ ceramics densified by spark plasma sintering, J. Eur. Ceram. Soc. 20 (2000) 2149-2152.

[30] Y. Gao, Y.J. Wu, X.M. Chen, J.P. Cheng, Y.Q. Lin, Y. Ma, Dense $\mathrm{YMn}_{2} \mathrm{O}_{5}$ ceramics prepared by spark plasma sintering, J. Am. Ceram. Soc. 91 (2008) $3728-3730$. 
[31] W. Liao, R. Liang, G. Wang, F. Cao, X. Dong, Dielectric and tunable properties of columnar $\mathrm{Ba}_{0.6} \mathrm{Sr}_{0.4} \mathrm{TiO}_{3}-\mathrm{MgO}$ composites prepared by spark plasma sintering, Appl. Phys. Lett. 99 (2011) 202905.

[32] Y. Pu, M. Yao, L. Zhang, P. Jing, High energy storage density of 0.55 $\mathrm{Bi}_{0.5} \mathrm{Na}_{0.5} \mathrm{TiO}_{3}-0.45 \mathrm{Ba}_{0.85} \mathrm{Ca}_{0.15} \mathrm{Ti}_{0.9-\mathrm{x}} \mathrm{Zr}_{0.1} \mathrm{Sn}_{\mathrm{x}} \mathrm{O}_{3}$ ceramics, J. Alloys Compd. 687 (2016) 689-695.

[33] X. Hao, A review on the dielectric materials for high energy-storage application, J. Adv. Dielectr. 3 (2013) 1330001.

[34] W.B. Li, D. Zhou, B. He, F. Li, L.X. Pang, S.G. Lu, Structure and dielectric properties of $\mathrm{Nd}\left(\mathrm{Zn}_{1 / 2} \mathrm{Ti}_{1 / 2}\right) \mathrm{O}_{3}-\mathrm{BaTiO}_{3}$ ceramics for energy storage applications, J. Alloys Compd. 685 (2016) 418-422.

[35] P. Khanchaitit, K. Han, M.R. Gadinski, Q. Li, Q. Wang, Ferroelectric polymer networks with high energy density and improved discharged efficiency for dielectric energy storage, Nat. Commun. 4 (2013) 2845.

[36] X. Wang, J. Shen, T. Yang, Y. Dong, Y. Liu, High energy-storage performance and dielectric properties of antiferroelectric $\left(\mathrm{Pb}_{0.97} \mathrm{La}_{0.02}\right)\left(\mathrm{Zr}_{0.5} \mathrm{Sn}_{0.5-\mathrm{x}} \mathrm{Ti}_{\mathrm{x}}\right) \mathrm{O}_{3}$ ceramic, J. Alloys Compd. 655 (2016) 309-313.

[37] L. Zhang, S. Jiang, B. Fan, G. Zhang, Enhanced energy storage performance in $\left(\mathrm{Pb}_{0.858} \mathrm{Ba}_{0.1} \mathrm{La}_{0.02} \mathrm{Y}_{0.008}\right)\left(\mathrm{Zr}_{0.65} \mathrm{Sn}_{0.3} \mathrm{Ti}_{0.05}\right) \mathrm{O}_{3}-\left(\mathrm{Pb}_{0.97} \mathrm{La}_{0.02}\right)\left(\mathrm{Zr}_{0.9} \mathrm{Sn}_{0.05} \mathrm{Ti}_{0.05}\right) \mathrm{O}_{3}$ anti-ferroelectric composite ceramics by spark plasma sintering, J. Alloys Compd. 622 (2015) 162-165.

[38] Q. Xu, T. Li, H. Hao, S. Zhang, Z. Wang, M. Cao, Z. Yao, H. Liu, Enhanced 
energy storage properties of $\mathrm{NaNbO}_{3}$ modified $\mathrm{Bi}_{0.5} \mathrm{Na}_{0.5} \mathrm{TiO}_{3}$ based ceramics, $\mathrm{J}$. Eur. Ceram. Soc. 35 (2015) 545-553.

[39] H. Tang, H.A. Sodano, Ultra high energy density nanocomposite capacitors with fast discharge using $\mathrm{Ba}_{0.2} \mathrm{Sr}_{0.8} \mathrm{TiO}_{3}$ nanowires, Nano Lett. 13 (2013) $1373-1379$.

[40] Q. Chen, Y. Wang, X. Zhou, Q.M. Zhang, S. Zhang, High field tunneling as a limiting factor of maximum energy density in dielectric energy storage capacitors, Appl. Phys. Lett. 92 (2008) 142909.

[41] L.C. Stearns, M.P. Harmer, Particle-inhibited grain growth in $\mathrm{Al}_{2} \mathrm{O}_{3}$-SiC: I, experimental results, J. Am. Ceram. Soc. 79 (1996) 3013-3019.

[42] A. Shaikh, R. Vest, Dielectric properties of ultrafine grained $\mathrm{BaTiO}_{3}$, IEEE Trans. Ultrason. Ferroelectr. Freq. Control. 36 (1989) 407-412.

[43] Z. Zhao, V. Buscaglia, M. Viviani, M.T. Buscaglia, L. Mitoseriu, A. Testino, M. Nygren, M. Johnsson, P. Nanni, Grain-size effects on the ferroelectric behavior of dense nanocrystalline $\mathrm{BaTiO}_{3}$ ceramics, Phys. Rev. B. 70 (2004) $1-8$.

[44] T. Hungría, H. Amorín, M. Algueró, A. Castro, Nanostructured ceramics of $\mathrm{BiScO}_{3}-\mathrm{PbTiO}_{3}$ with tailored grain size by spark plasma sintering, Scr. Mater. 64 (2011) 97-100.

[45] Q. Li, K. Han, M.R. Gadinski, G. Zhang, Q. Wang, High energy and power density capacitors from solution-processed ternary ferroelectric polymer nanocomposites, Adv. Mater. 26 (2014) 6244-6249. 


\section{Figure captions}

Fig. 1. Flow chart of the synthesis of $\mathrm{Ba}_{0.4} \mathrm{Sr}_{0.6} \mathrm{TiO}_{3}$ powders by sol-gel method.

Fig. 2. XRD patterns of $\mathrm{Ba}_{0.4} \mathrm{Sr}_{0.6} \mathrm{TiO}_{3}$ powders calcined at various temperatures.

Fig. 3. SEM micrographs of $\mathrm{Ba}_{0.4} \mathrm{Sr}_{0.6} \mathrm{TiO}_{3}$ powders calcined at various temperatures:

(a) $750^{\circ} \mathrm{C}$, (b) $850^{\circ} \mathrm{C}$, (c) $950^{\circ} \mathrm{C}$, and (d) $1050^{\circ} \mathrm{C}$.

Fig. 4. SEM micrographs on polished and thermally etched surfaces of $\mathrm{Ba}_{0.4} \mathrm{Sr}_{0.6} \mathrm{TiO}_{3}$ ceramics sintered at $1000^{\circ} \mathrm{C}$ for $5 \mathrm{~min}$ by SPS from powders calcined at different temperatures: (a) $750^{\circ} \mathrm{C}$, (b) $850^{\circ} \mathrm{C}$, (c) $950^{\circ} \mathrm{C}$ and (d) $1050^{\circ} \mathrm{C}$.

Fig. 5. Temperature dependence of dielectric constant and dielectric loss at various frequencies for $\mathrm{Ba}_{0.4} \mathrm{Sr}_{0.6} \mathrm{TiO}_{3}$ ceramics prepared from powders calcined at different temperatures: (a) (e) $750^{\circ} \mathrm{C}$, (b)(f) $850^{\circ} \mathrm{C},(\mathrm{c})(\mathrm{g}) 950^{\circ} \mathrm{C}$, and (d)(h) $1050^{\circ} \mathrm{C}$.

Fig. 6. (a) Average grain size and the maximum dielectric constant at $100 \mathrm{~Hz}$ and (b) dielectric constant and dielectric loss at room temperature and $100 \mathrm{~Hz}$ for BST ceramics prepared from powders calcined at different temperatures.

Fig. 7. $P-E$ loops at room temperature and $60 \mathrm{~Hz}$ for $\mathrm{Ba}_{0.4} \mathrm{Sr}_{0.6} \mathrm{TiO}_{3}$ ceramics prepared from powders calcined at different temperatures: (a) $750^{\circ} \mathrm{C}$, (b) $850^{\circ} \mathrm{C}$, (c) $950^{\circ} \mathrm{C}$, and (d) $1050^{\circ} \mathrm{C}$.

Fig. 8. (a) Energy storage density and (b) energy storage efficiency as a function of applied electric field for $\mathrm{Ba}_{0.4} \mathrm{Sr}_{0.6} \mathrm{TiO}_{3}$ ceramics prepared from powders calcined at different temperatures. 


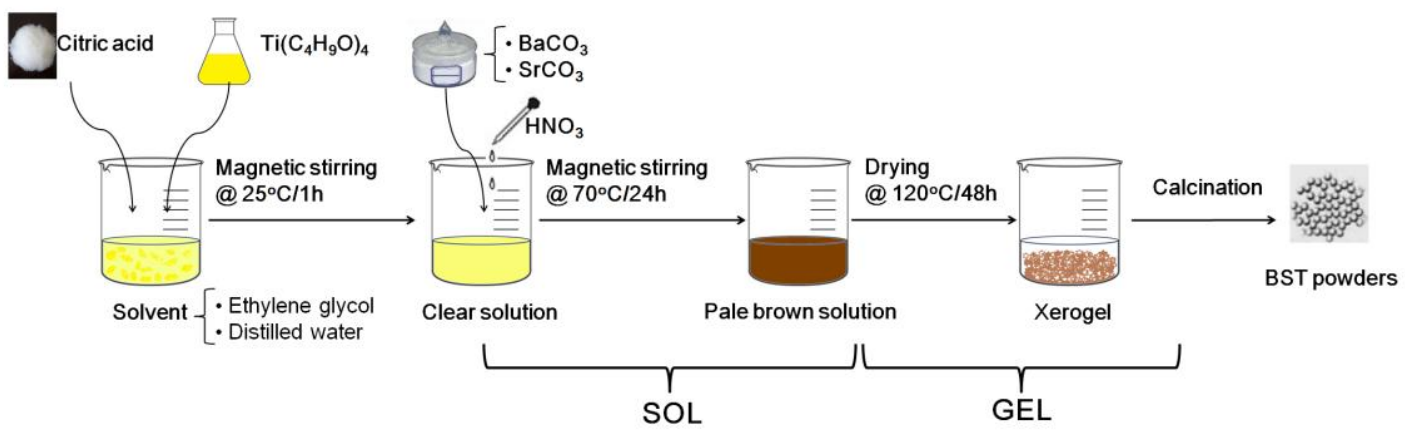




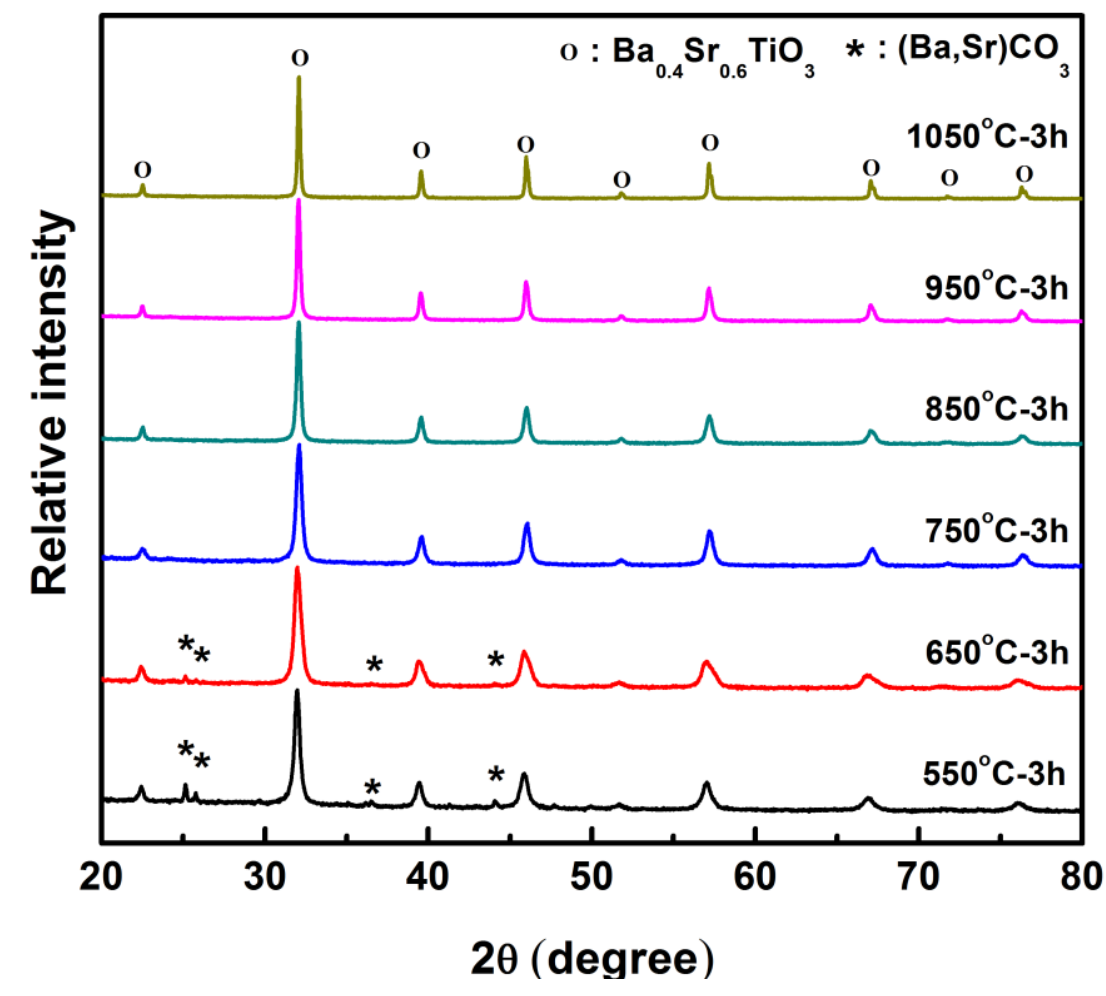



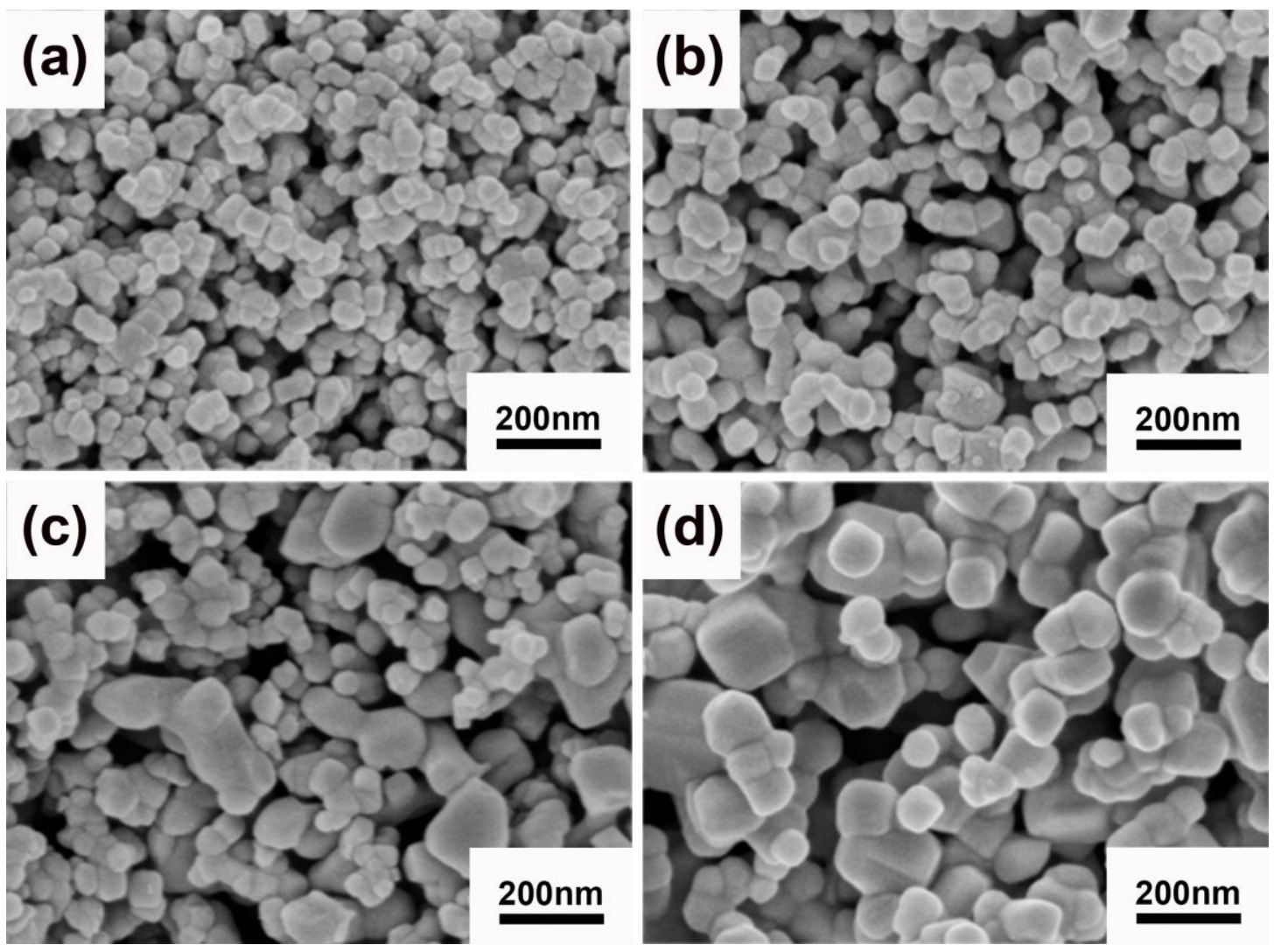

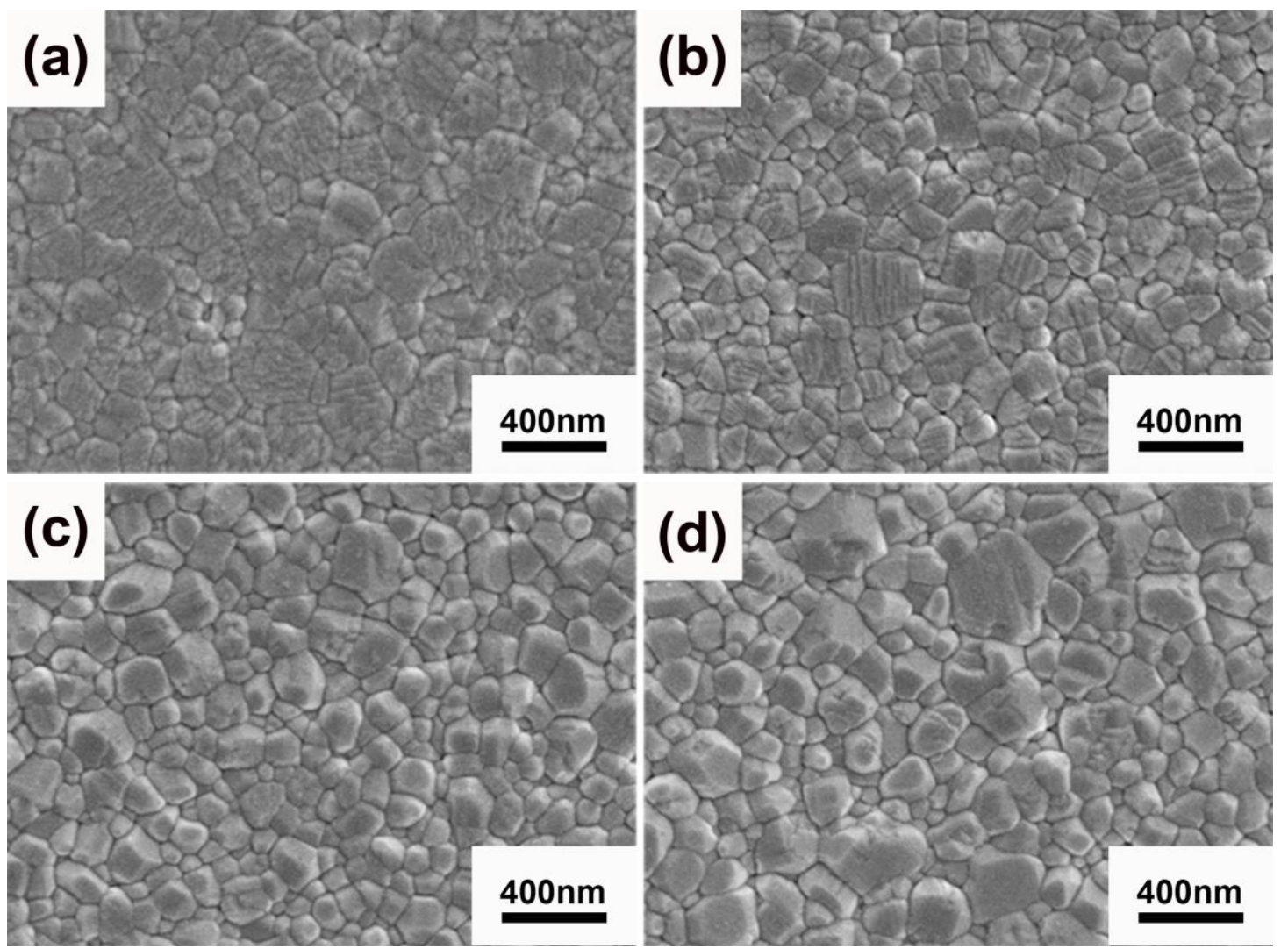

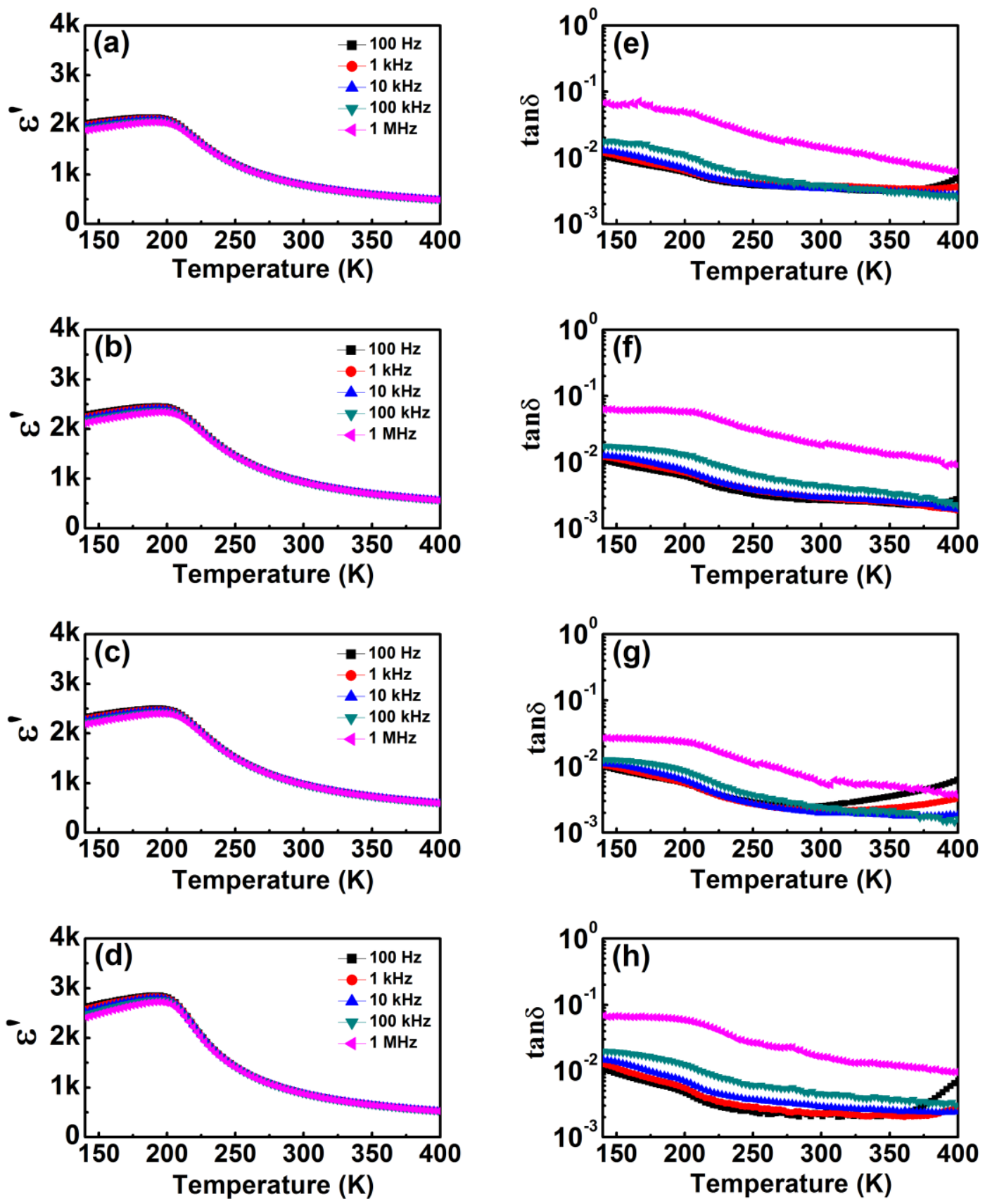

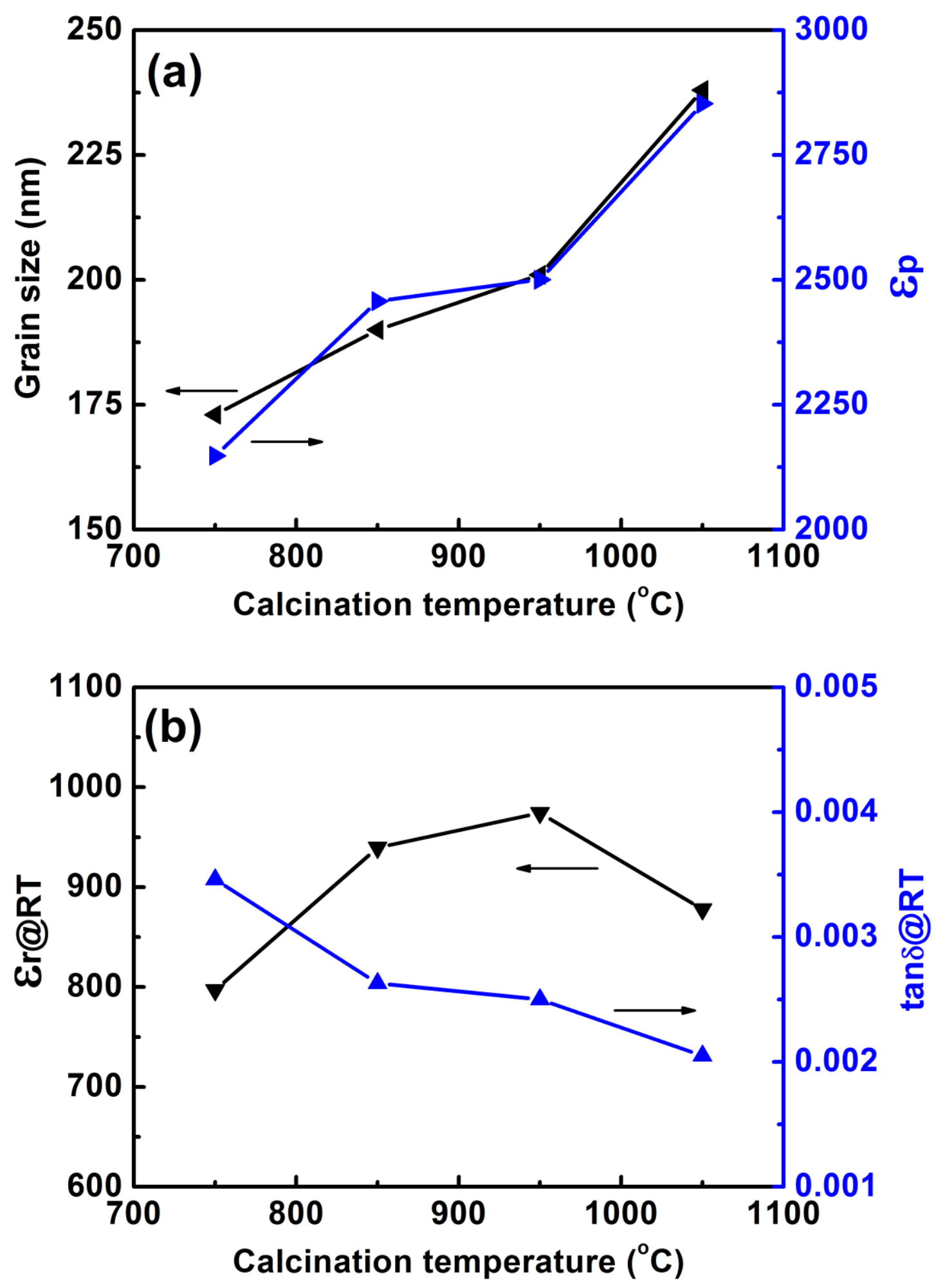

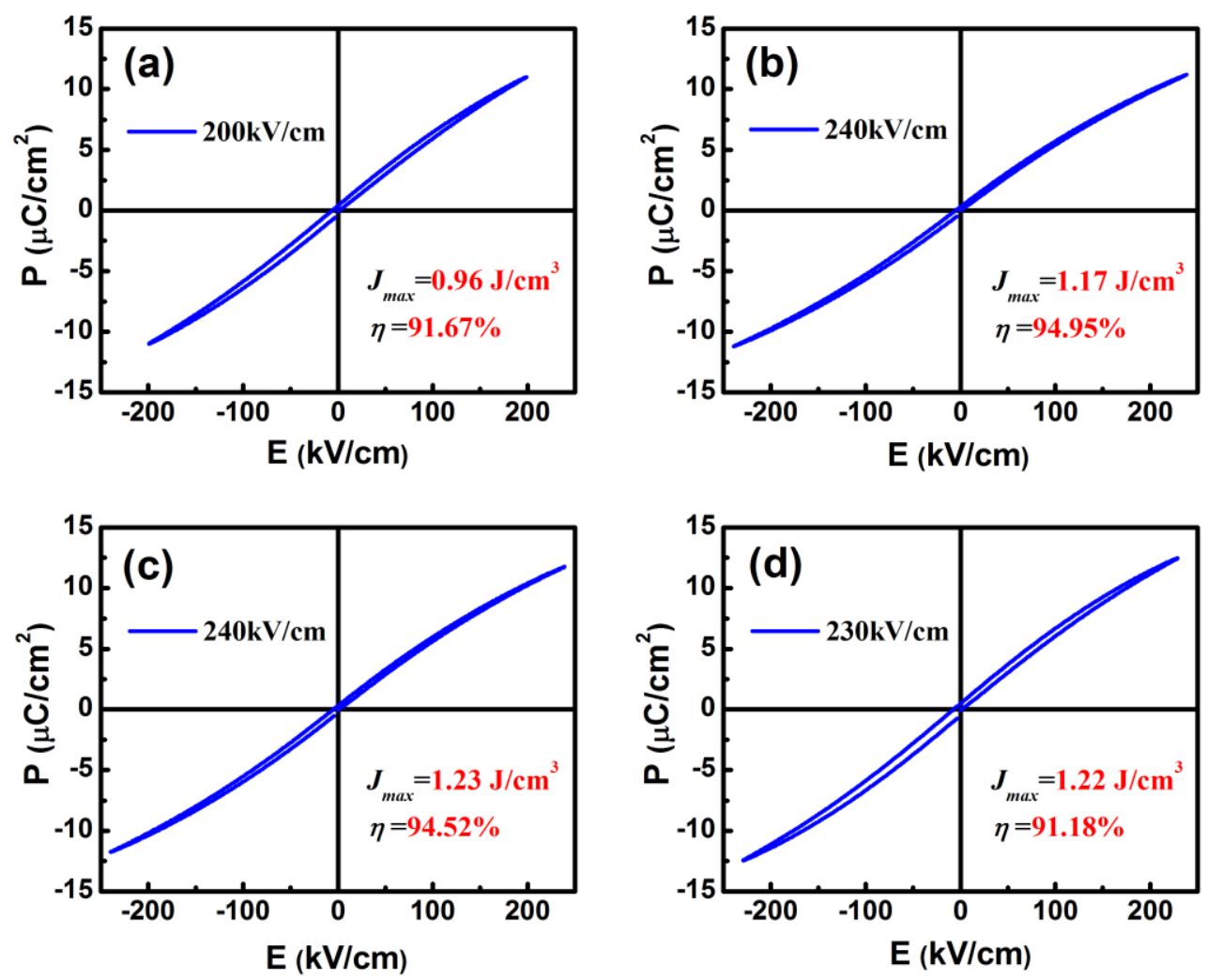

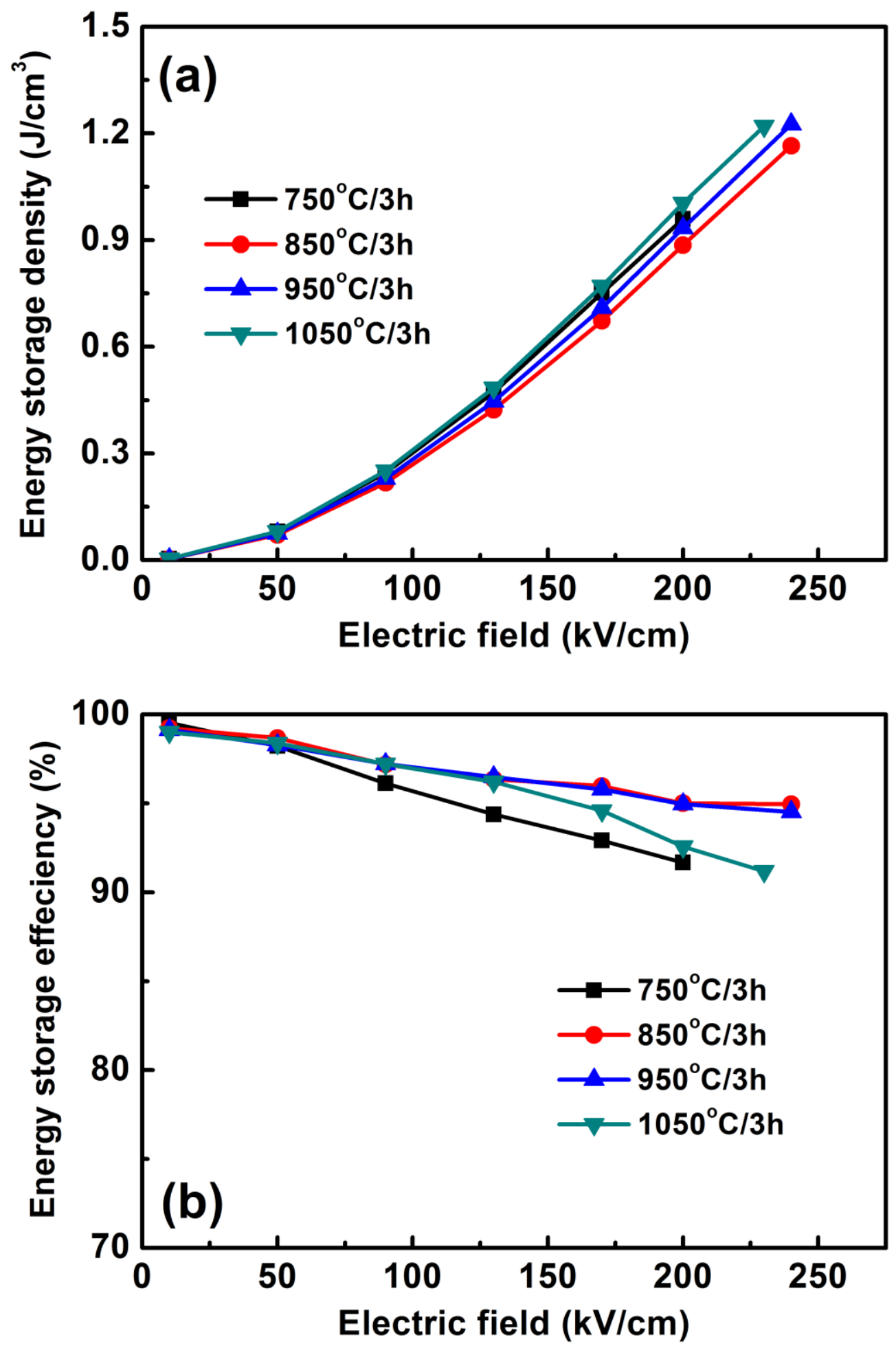
Table 1. Dielectric constant and dielectric loss at room temperature and $100 \mathrm{~Hz}$ for $\mathrm{Ba}_{0.4} \mathrm{Sr}_{0.6} \mathrm{TiO}_{3}$ ceramics prepared from powders calcined at different temperatures.

\begin{tabular}{cccc}
\hline $\begin{array}{c}\text { Calcination } \\
\text { temperature }\end{array}$ & $\begin{array}{c}\text { SPS } \\
\text { conditions }\end{array}$ & $\begin{array}{c}\text { Dielectric constant } \\
\varepsilon_{\mathrm{r}}\end{array}$ & $\begin{array}{c}\text { Dielectric loss } \\
\text { tan } \delta\end{array}$ \\
\hline $750^{\circ} \mathrm{C} / 3 \mathrm{~h}$ & $1000^{\circ} \mathrm{C} / 5 \mathrm{~min}$ & 792.6 & 0.0035 \\
$850^{\circ} \mathrm{C} / 3 \mathrm{~h}$ & $1000^{\circ} \mathrm{C} / 5 \mathrm{~min}$ & 931.7 & 0.0026 \\
$950^{\circ} \mathrm{C} / 3 \mathrm{~h}$ & $1000^{\circ} \mathrm{C} / 5 \mathrm{~min}$ & 968.7 & 0.0025 \\
$1050^{\circ} \mathrm{C} / 3 \mathrm{~h}$ & $1000^{\circ} \mathrm{C} / 5 \mathrm{~min}$ & 887.1 & 0.0021 \\
\hline
\end{tabular}


Table 2. Maximum polarization $\left(P_{\max }\right)$, remnant polarization $\left(P_{r}\right)$, dielectric breakdown field $\left(E_{b}\right)$, energy storage density $\left(J_{c}\right)$ and energy storage efficiency $(\eta)$ of $\mathrm{Ba}_{0.4} \mathrm{Sr}_{0.6} \mathrm{TiO}_{3}$ ceramics at room temperature.

\begin{tabular}{ccccccc}
\hline $\begin{array}{c}\text { Calcination } \\
\text { Temperature }\end{array}$ & $\begin{array}{c}\text { SPS } \\
\text { Conditions }\end{array}$ & $\begin{array}{c}\mathbf{P}_{\text {max }} \\
\left(\mu \mathbf{C} / \mathbf{c m}^{2}\right)\end{array}$ & $\begin{array}{c}\mathbf{P}_{\mathbf{r}} \\
\left(\boldsymbol{\mu C} / \mathbf{c m}^{2}\right)\end{array}$ & $\begin{array}{c}\mathbf{E}_{\mathbf{b}} \\
(\mathbf{k V} / \mathbf{c m})\end{array}$ & $\begin{array}{c}\boldsymbol{J}_{\boldsymbol{c}} \\
\left(\mathbf{J} / \mathbf{c m}^{3}\right)\end{array}$ & $\boldsymbol{\eta}$ \\
\hline $750^{\circ} \mathrm{C} / 3 \mathrm{~h}$ & $1000^{\circ} \mathrm{C} / 5 \mathrm{~min}$ & 11.00 & 0.41 & 200 & 0.96 & $91.67 \%$ \\
$850^{\circ} \mathrm{C} / 3 \mathrm{~h}$ & $1000^{\circ} \mathrm{C} / 5 \mathrm{~min}$ & 11.21 & 0.29 & 240 & 1.17 & $94.95 \%$ \\
$950^{\circ} \mathrm{C} / 3 \mathrm{~h}$ & $1000^{\circ} \mathrm{C} / 5 \min$ & 11.76 & 0.27 & 240 & 1.23 & $94.52 \%$ \\
$1050^{\circ} \mathrm{C} / 3 \mathrm{~h}$ & $1000^{\circ} \mathrm{C} / 5 \min$ & 12.46 & 0.45 & 230 & 1.22 & $91.18 \%$ \\
\hline
\end{tabular}

